\title{
Nexus between stock exchange index and exchange rates
}

\author{
Md. Zahangir Alam ${ }^{1, ~ *, ~ M u h a m m a d ~ A b d u r ~ R a h i m ² ~}$ \\ ${ }^{1}$ Department of Business Adminsitration, International Islamic University Chittagong, Dhaka Campus, Bangladesh \\ ${ }^{2}$ General Banking Department, Main Branch, Mercantile Bank Ltd., Dhaka, Bangladesh
}

\section{Email address:}

mzafinance@gmail.com (M. Z. Alam),rahimcuctg@yahoo.com (M. A. Rahim)

To cite this article:

Md Zahangir Alam, Muhammad Abdur Rahim. Nexus between Stock Exchange Index and Exchange Rates. International Journal of Economics, Finance and Management Sciences.Vol. 1, No. 6, 2013, pp. 330-334. doi: 10.11648/j.ijefm.20130106.20

\begin{abstract}
This study is about to analyze the nexus between stock exchange index and exchange rates. Secondary data, namely the daily Dhaka Stock Exchange General Index and the BDT/USD Exchange Rates data from December 02,2012 to April 30, 2012 are used for the study perpose. The findings of this study revealed that $73.1802 \%$ of the variation in DSE general index returns is explained by the BDT/USD exchange rates returns which imply that there is a strong nexus between these two financial series. LM test's outcomes indicate that there is a serial correlation at order 1; historical figures of the residuals can be applied to predict the present values of residuals. ARCH test illustrates that the residuals are heteroskedastic; and variance of residuals is not constant. Normality test of the distribution of the residuals shows that the residuals are normally distributed.
\end{abstract}

Keywords: ARCH, LM, Stock Index, Exchange Rates

\section{Introduction}

Stock market indices have turned into a significant indicator of a sound economy in a country which implies the importance of stock market. This increasing significance of the stock market has intensified the development of various theories for explaining the functioning of stock markets. As per the parity condition, interest rates and the exchange rates are supposed to be associated with a negative coefficient, therefore the relationship between exchange rates and stock indices should be positive (Hamrita and Trifi, 2011). Foreign exchange rate plays an important role in making linkage between domestic market and rest of the world. Each nation searches for adopting its own exchange rate regime which helps to attain four basic goals. First, maintain stable exchange rate which has a positive impact on Foreign Direct Investment (FDI) and steady relative price through minimizing exchange rates risk. Second, lessen inflationary pressure for protecting home price. Third, maintain external balance which is applicable when balance of payment is near about zero. Fourth, uphold occupied employment level. Theoretically, the association involving stock prices and exchange rates has two essential approaches, namely flow-oriented as well as well stock - oriented. First, the impact of exchange rates on the stock market and stock oriented states that depreciation of exchange rates will enhance competitiveness that increase in domestic output, as a result stock market is expanded. Second, the impact of the stock prices on exchange rates mentions that an increase in stock price attract capital inflows which raises demand for local currency and causes the appreciation of exchange rates (Alhayky and Houdou, 2009). The association between stock prices and exchange rates has concerned the attitudes of economists as they both play significant roles in influencing the development of a country's economy. In the recent years, cross-market return associations, gradual abolishment of capital inflow obstacle and exchange limitations or the acceptance of more flexible exchange rate arrangements in emerging and transition countries, these two markets have become mutually dependent due to increasing international diversification. These changes have improved a variety of investment opportunities and the volatility of exchange rates and risk of investment decisions as well as portfolio diversification process (Aydemir and Demirhan, 2009). The core objective of this study is to critically examine the nexus between stock exchange index and exchange rates

\section{Literature Review}

Hamrita and Trifi (2011) have found that the association between interest rate and the exchange rate is not significantly different from zero, while the association between interest rate returns and stock index returns is significantly deviated from zero only at the highest scales. They have also 
mentioned that the exchange rate returns and stock index returns have a bidirectional relationship in their study period at longer horizons. According to Aggarwal (1981), stock market indices and exchange rates are positively associated. Ma and Kao (1990) have found that for an export dominating economy, currency appreciation affects stock indices, whereas opposite impact is applicable for an import dominating country. Morley and Pentecost (2000) have revealed that the stock markets and exchange rates are allied, but this relationship is through a general cyclical pattern, rather than a common trend. Franck and Young (1972); and Ang and Ghallab (1976) have found no reaction of stock price to the exchange rate realignments. Soenen and Hennigar (1988) revealed a strong negative association between the exchange rates and stock price. Solnik(1987) has found that differentials in real stock return (RSR) and changes in real exchange rates (RER) are inversely related .Morley (2002) has disclosed a stable short-term association between the stock price and exchange rates in UK and Netherlands, whereas fragile substantiation of association in Italy and France and no evidence of relationship in Germany. Mishra (2004) has found no consistent relationship between stock returns, exchange rate returns, demand for money and interest rate. Ibrahim and Aziz (2003) have revealed no interaction exists between the stock prices and the exchange rates, the industrial production, the money supply, and the price level. Oskooee and Sohrabian (1992) have revealed that there is bidirectional causality between stock prices and effective exchange rate, at least in the short-term, where as it has been found that there is no long-term association between two variables. Aydemir and Demirhan (2009) have revealed that bidirectional association exists between exchange rates and all stock indices. They have also found that there is an inverse causal relationship between exchange rates and all stock market indices. Reddy and Sebastin (2008) have found that there is a low level of interaction between the stock and the forex market of India at a time scale of a day or less, though theory advices interactive association between the two markets. Ratanapakorn and Sharma (2007) have found that the stock prices and long-term interest rates are inversely related, while money supply, industrial production, inflation, the exchange rate and the short-run interest rate are positively associated. Alhayky and Houdou (2009) have found that there is a long-run association between Kuwait Stock Price Index and exchange rates for US Dollar, Japanese Yen, and British Pound, whereas there is no long-term relationship between Kuwait Stock Price Index and EURO. Ismail and Isa (2009) have revealed that exchange rates depreciate due to decrease in stock price index and exchange rates appreciate due to increase in stock price index. Sampath (2011) has revealed that there is a significant association between economic growth and stock prices in India. Srinivasan (2011) has found that the NSE-Nifty share price index and exchange rates in the long-term are inversely related. Ajayi and Mougoue (1996) have found that an appreciation in aggregate domestic stock prices has an inverse short-term impact on the home currency value, while cur- rency depreciation has a negative short-term and long-term impact on the stock market.

\section{Data and Methodology}

\subsection{Data}

Only secondary data is used in this study. Dhaka Stock Exchange General Index (DSEGINDX) as well as the BDT/USD Exchange Rates (BUER) data is collected to conduct this analyis on daily basis. A 2393 trading day from December 02, 2012 to April 30, 2012 have been considered for the study purpose.

\subsection{Normality Test of the Data}

Jarque-Bera statistics is used to test the normality of the DSEGINDX series and the BUER.

Figure 1. and figure 2. demonstrate that both the skewness and kurtosis are positive. Based on the Jarque-Bera statistics, both DSE general index as well as the BDT/USD series is non-normal at $95 \%$ confidence interval, because in both cases probability is less than 0.05 . So, the indication is that both the series requires some type of transformation.

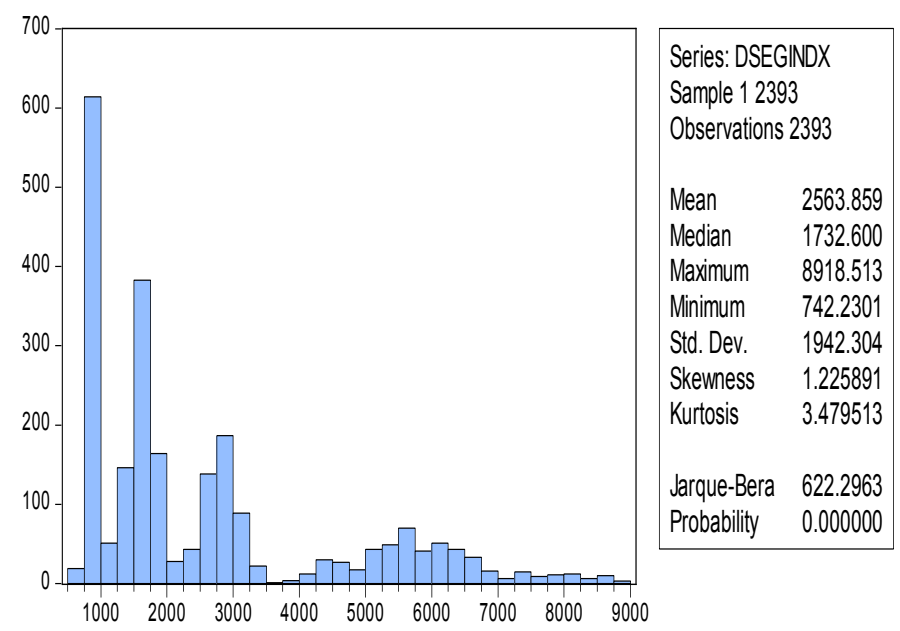

Figure 1. DSE General Index Summary Statistica

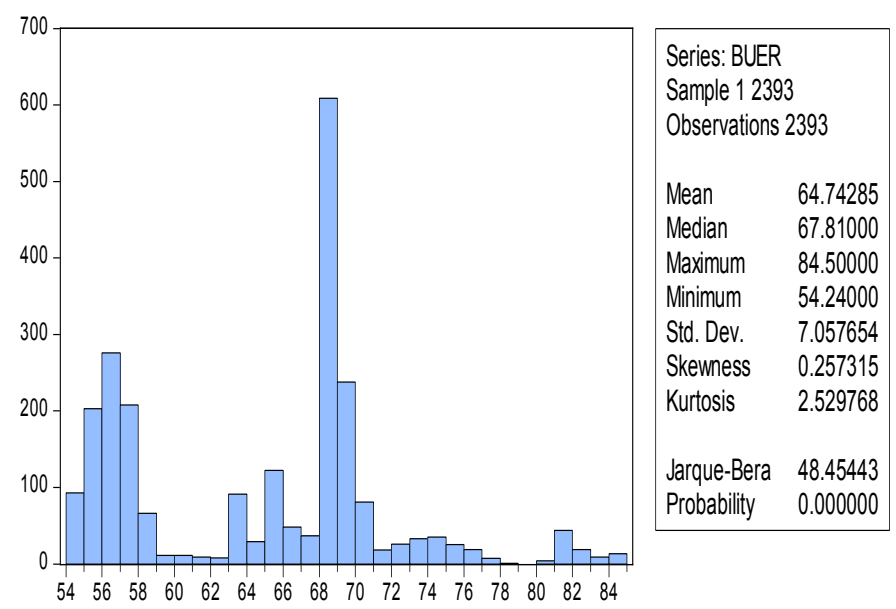

Figure 2. BDT/USD Exchange Rates Summary Statistica 


\subsection{Transformation of the DSE General Index and the BDT/USD Exchange Rates Series}

The DSE general index and BDT/USD exchange rates are transformed into returns by using the following equations:

$$
\begin{aligned}
& \text { RDSEGINDX }=\log (\text { DSEGINDX) } \\
& \text { RBUER }=\log (\text { BUER })
\end{aligned}
$$

\subsection{Stationary Test of DSE General Index Return and BDT/USD Exchange Rates Return}

Augmented Dickey-Fuller (ADF) Test and Phillips-Perron (PP) Test on DSEGINDX returns and BUER returns series are done for stationary test of data:

Table 1. ADF Test on DSE20 Index Returns

\begin{tabular}{cccc}
\hline & & t-Statistic & Prob.* \\
\hline $\begin{array}{c}\text { Augmented Dick- } \\
\text { ey-Fuller test statistic }\end{array}$ & & -0.563588 & 0.8760 \\
& $1 \%$ level & -3.432897 & \\
Test critical values: & $5 \%$ level & -2.862551 & \\
& $10 \%$ level & -2.567354 & \\
\hline
\end{tabular}

*MacKinnon (1996) one-sided p-values.

Table 2. ADF Test on the BDT/USD Exchange Rates Returns

\begin{tabular}{cccc}
\hline & & Adj. t-Stat & Prob. $^{*}$ \\
\hline $\begin{array}{c}\text { Augmented Dick- } \\
\text { ey-Fuller test statis- } \\
\text { tic }\end{array}$ & & 0.196740 & 0.9724 \\
& & & \\
& & & \\
Test critical values: & $5 \%$ level & -3.432899 & \\
& $10 \%$ level & -2.862552 & \\
& -2.567354 & \\
\hline
\end{tabular}

*MacKinnon (1996) one-sided p-values.

The outputs of ADF tests on DSE general index returns and the $\mathrm{BDT} / \mathrm{USD}$ exchange rates returns are presented in the table 1 and 2, show that the DSE general index returns and the BDT/USD exchange rates returns are non-stationary, since the test statistics values are greater than the test critical values at $5 \%$ level of significance.

Table 3. PP Test on the DSE General Index Returns

\begin{tabular}{cccc}
\hline & & Adj. t-Stat & Prob.* \\
\hline $\begin{array}{c}\text { Phillips-Perron } \\
\text { test statistic }\end{array}$ & & -0.468788 & 0.8947 \\
Test critical val- & $1 \%$ level & & -3.432889 \\
ues: & $5 \%$ level & & -2.862548 \\
& $10 \%$ level & & -2.567352 \\
\hline
\end{tabular}

*MacKinnon (1996) one-sided p-values
Table 4. PP Test on the BDT/USD Exchange Rates Returns

\begin{tabular}{cccc}
\hline & & Adj. t-Stat & Prob.* \\
\hline $\begin{array}{c}\text { Phillips-Perron test } \\
\text { statistic }\end{array}$ & & 0.279918 & 0.9773 \\
& & -3.432889 & \\
Test critical values: & $5 \%$ level & -2.862548 & \\
& $10 \%$ level & -2.567352 & \\
\hline
\end{tabular}

*MacKinnon (1996) one-sided p-values

The results of the PP tests on both the DSE general index returns and $\mathrm{BDT} / \mathrm{USD}$ exchange rates returns are presented in the table 3 and 4, prove that the DSE general index returns and the BDT/USD exchange rates returns are non-stationary, because since the test statistics values are greater than the test critical values at $5 \%$ level of significance.

\subsection{Specification of the Model}

In this study, simple regression model has been applied to evaluate the interaction between the BDT/USD exchange rates returns and the DSE general index returns during the study period. This model shows the degree of relationship between independent variable (s) and dependent variable and it takes the following form:

$$
\hat{\mathrm{Y}}=\beta_{0}+\beta_{1} \mathrm{X}_{1}
$$

Where,

$\hat{Y}=$ Dependent variable, i.e., RDSEGINDX

$\mathrm{X}_{1}=$ Independent variable, i.e. RBUER

$\beta_{0}=$ Intercept term (value of dependent variable in absence of independent variable)

$\beta_{1}=$ slope (change in dependent variable due to one unit change in independent variable)

\subsection{Testing of the Results of Estimated Model}

Breusch-Godfrey test (LM test), ARCH test, and the Jarque-Bera test are used in this study for testing the outcomes of the estimated regression model.

\section{Empirical Results}

\subsection{Estimation of the Regression Model}

The estimated regression model takes the following form:

$$
\hat{Y}=-15.72382+5.598249 X_{1}
$$


Table 5. Output of the Estimated Model

\begin{tabular}{|c|c|c|c|c|}
\hline \multicolumn{5}{|c|}{$\begin{array}{l}\text { Dependent Variable: RDSEGIN } \\
\text { Method: Least Squares } \\
\text { Date: } 8 / 26 / 13 \quad \text { Time: } 17: 35 \\
\text { Sample: } 12393 \\
\text { Included observations: } 2393\end{array}$} \\
\hline Variable & Coefficient & Std. Error & t-Statistic & Prob. \\
\hline $\mathrm{C}$ & -15.72382 & 0.288739 & -54.45689 & 0.0000 \\
\hline RBUER & 5.598249 & 0.069310 & 80.77167 & 0.0000 \\
\hline R-squared & 0.731802 & Mean dependent var & & 7.590164 \\
\hline Adjusted R-squared & 0.731690 & S.D. dependent var & & 0.711250 \\
\hline S.E. of regression & 0.368418 & Akaike info criterion & & 0.841637 \\
\hline Sum squared resid & 324.5345 & Schwarz criterion & & 0.846468 \\
\hline Log likelihood & -1005.019 & Hannan-Quinn criter. & & 0.843395 \\
\hline F-statistic & 6524.063 & Durbin-Watson stat & & 0.010660 \\
\hline Prob(F-statistic) & 0.000000 & & & \\
\hline
\end{tabular}

5.598249 is the regression coefficient of RBUER and indicates that with the influence of RDSEGINDX held constant, as RBUER increases (or decreases), say by one percent, on average, RDSEGINDX increases (or decreases) by 5.598249 percent. Therefore, the BDT/USD exchange rates returns have a significant positive effect on the DSE general index returns series. The intercept value, -15.72382, mechanically interpreted, means that if the value of RBUER is fixed at zero, the value of RDSEGINDX would be -15.72382. Therefore, mathematically it can be mentioned that the DSE general index returns would be -15.72382 while GDP while other things remain constant. The R -squared value, 0.731802 , means that 73.1802 percent of the variation in RDSEGINDX is explained by RBUER, a fairly high value considering that the maximum value of R-squared can at most be 1 .

\subsection{Testing of Results of the Estimated Model}

\subsubsection{Breusch-Godfrey Serial Correlation LM Test}

Table 6. Output of Breusch-Godfrey Serial Correlation LM Test

\begin{tabular}{cccc}
\hline F-statistic & $\mathbf{2 2 2 6 8 7 . 2}$ & Prob. F(1,2390) & $\mathbf{0 . 0 0 0 0}$ \\
\hline Obs*R-squared & 2367.590 & Prob. Chi-Square(1) & 0.0000 \\
\hline
\end{tabular}

Table 6 shows that there is a serial correlation, i.e. the past values of the residuals can be used to predict the current values of residuals, since the probability $F(1,2390)$ is 0.0000 which is less than 0.05 .

\subsubsection{Test of No Heteroskedasticity by Using Autoregres- sive Conditional Heteroskedasticity (ARCH) Test}

Table 7. Heteroskedasticity Test: ARCH

\begin{tabular}{cccc}
\hline F-statistic & $\mathbf{8 5 2 8 8 . 6 8}$ & Prob. F(1,2390) & $\mathbf{0 . 0 0 0 0}$ \\
\hline Obs*R-squared & 2326.797 & Prob. Chi-Square(1) & 0.0000 \\
\hline
\end{tabular}

Table 7 demonstrates that that the residuals are heteroskedastic, i.e. the variance of residuals is not constant, since the probability $F(1,2390)$ is 0.0000 which is less than 0.05 .

\subsubsection{Test of Normality of the Distribution of the Residuals}

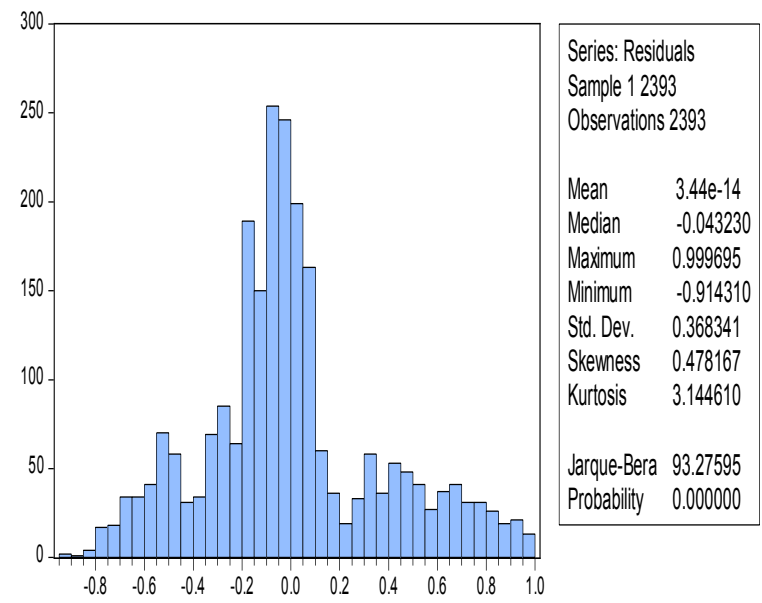

Figure 3. Normality Test of Residual

Figure 3 demonstrates that the residuals are normally distributed, since the p-value (probability) is 0.0000 which is less than 0.05 .

\section{Conclusion}

The estimated model shows that DSE general index returns are increased (or decreased) by $5.598249 \%$ due to $1 \%$ increase or decrease in BDT/USD exchange rates returns which implies that the BDT/USD exchange rates returns have a significant positive effect on the DSE general index returns series. Mathematically, it is found that the DSE 
general index returns would be -15.72382 while GDP if the value of RBUER is fixed at zero, while other things remain constant. It is revealed that 73.1802 percent of the variation in DSE general index returns is explained by the BDT/USD exchange rates returns, a fairly high value considering that the maximum value of $\mathrm{R}$-squared can at most be 1 . The results of Breusch - Godfrey serial correlation LM test shows that there is a serial correlation at order 1, i.e. the past values of the residuals can be used to predict the current values of residuals. The $\mathrm{ARCH}$ test displays that the residuals are heteroskedastic, i.e. the variance of residuals is not constant. Normality test of the distribution of the residuals exhibits that the residuals are normally distributed, since the p-value (probability) is less than 0.05 .

\section{References}

[1] Aggarwal, R. (1981). Exchange rates and stock prices: A study of U.S. capital markets under floating exchange rates. Akron Business and Economics Review, 12(2), 7-12.

[2] Alhayky, A. and Houdou, O. (2009). Stock prices and exchange rates: Empirical evidence from Kuwait's financial markets. The IUP Journal of Financial Economics, 7 ( 3 \& 4), 71-83.

[3] Ajayi, R. A. and Mougoue. M. (1996) . On the dynamic relation between stock prices and exchange rates. Journal of Financial Research, 19, 193-207.

[4] Ang, J. S. and Ghallab, A. (1976) . The impact of US devaluation on the stock prices of multinational cooperations. Journal of Business Research, 4, 25-34.

[5] Aydemir, O. and Demirhan, E. ( 2009) . The relationship between stock prices and exchange rates evidence from Turkey. International Research Journal of Finance and Economics, 23, 207- 215.

[6] Franck, P and Young, A. (1972 ). Stock price reaction of multinational firms to exchange realignments. Financial Management, 1, 66-73.

[7] Hamrita, M. E. and Trifi, A. (2011). The relationship between interest rate, exchange rate and stock price: A wavelet analysis. International Journal of Economics and Financial Issues, 1( 4), 220-228.
[8] Ismail, M. T. and Isa, Z. B. ( 2009) . Modeling the interactions of stock price and exchange rate in Malaysia. The Singapore Economic Review, 54 (4), 605-619.

[9] Ma, C.K. and Kao, G.W. ( 1990). On exchange rate changes and stock price reactions. Journal of Business and Accounting, 17(2), 441-449.

[10] Mishra, A. K.. (2004). Stock market and foreign exchange market in India: Are they related. South Asian Journal of Management, 11, 12-31.

[11] Morley, B. and Pentecost, E. J., 2000 . Common trends and cycles in G-7 countries exchange rates and stock prices. Applied Economics Letters, 7, 7-10.

[12] Morley, B (2002). Exchange rates and stock prices: Implications for European convergence. Journal of Policy Modeling, $24,523-526$.

[13] Oskooee, M. B. and Sohrabian, A. (1992). Stock prices and the effective exchange rate of the dollar. Applied Economics, 24, 459-464.

[14] Ratanapakorn, O. and Sharma, S. C. ( 2007). Dynamic analysis between the US stock returns and the macroeconomic variables. Applied Financial Economics, 17, 369-377.

[15] Reddy, Y. V. and Sebastin, A. (2008). Interaction between forex and stock markets in India: An entropy approach. IKALPA, 33(4), 27-46.

[16] Sampath, T. (2011). Macroeconomic variables and stock prices in India: An empirical analysis. The IUP Journal of Monetary Economics, 9 (4), 40-53.

[17] Srinivasan, P. (2011). Causal nexus between stock market return and selected macroeconomic variables in India: Evidence from the National Stock Exchange (NSE). The IUP Journal of Financial Risk Management, 8( 4), 7-25.

[18] Solnik, B. (1987). Using financial prices to test rates models: A note. Journal of Finance, 42(1), 141-149.

[19] Soenen, L. A and Hennigar, E. S. (1988). An analysis of exchange rates and stock prices: The US experience between 1980 and 1986. Akron Business and Economic Review, 19, $7-16$. 